\title{
Influence of Real Exchange Rate and Volatility on FDI Inflow in Nigeria
}

\author{
Saidu D. Muhammad ${ }^{1}$, Nnanna P. Azu ${ }^{2}$, Ngozi F. Oko ${ }^{3}$ \\ ${ }^{1}$ School of Management, Dongbei University of Finance and Economics, Dalian, China \\ ${ }^{2}$ School of International Economics and Trade, Dongbei University of Finance and Economics, Dalian, China \\ ${ }^{3}$ Shenzhen Fanoc Trading Co., Ltd, Shenzhen, China \\ Correspondence: Nnanna P. Azu, School of International Economics and Trade, Dongbei University of Finance \\ and Economics, Dalian, China.
}

Received: April 6, 2018

doi:10.5539/ibr.v11n6p73
Accepted: April 30, $2018 \quad$ Online Published: May 9, 2018

URL: https://doi.org/10.5539/ibr.v11n6p73

\begin{abstract}
The purpose of this research is to ascertain the effect of real exchange rate fluctuation and its volatility on inward flow of FDI with Nigeria as a focal country, between 1970 to 2014. The research applied GARCH $(1,1)$ to ascertain the level of volatility and ARDL model was used to determine the relevant results-these techniques were adopted for their robustness in estimation. It could be revealed that the effects of exchange rate and exchange rate volatility are more of a short-run phenomenon; while devaluation would increase inflow of FDI, volatility makes foreign investors more sceptical with increasing uncertainty. Increasing uncertainty could deter inflow of FDI into the country. Having captured the effect of political regime in the model, the paper reveals that a democratic regime should be the mainstay since it attracts more foreign investment compared to the military regimes. Therefore, even though devaluation is good, it would be better under civil government regimes.
\end{abstract}

Keywords: FDI, Real exchange rate, volatility, GARCH, political regime

\section{Introduction}

Exchange rate fluctuation and its volatility has become a topical issue among policy makers and scholars alike in that it does not only impinge on profitability of firms that operate internationally, but is also influential in determining investment by foreign firms. Massive benefits are envisaged to be accrued to recipient nations of FDI with Goldberg and Klein (1998) asserting that FDI encourages export promotion, import substitution or greater trade in intermediate input which seldom exist between parent and affiliated producer. Other scholars believe there are positive links between FDI and economic growth and development (See Cipollina et al 2012, McCloud and Kumbhakar 2011, Wang and Wong 2008, Zhao and Du 2007, Liu et al 2014, Chaudhry et al 2013 and Adegbite and Ayadi 2010) but to the disagreement of Herzer (2012) who suggested that negative relationship exists between FDI and growth in developing countries (Akinlo 2004, Rehman 2016). Kiyota and Urata (2004) would reason that both investing and host countries do benefit from FDI. While the former benefit from market share increase through locational comparative advantage, strategic assets in $R \& D$ and stabilizing economic relation, the latter will gain from transfer of financial resources, technological and managerial know-how as well as offer healthy competitiveness to local firms and other spill-over advantages. The flow of FDI will involve changes in assets value to a different currency which could be tedious due to the fluctuation of currency values. It becomes apparent that policy makers need to investigate the relationship between exchange rate and its volatility as they affect FDI, to aid formulation of workable policies.

With Vision 2020:20 ${ }^{1}$ looming and paramount to economic development in Nigeria, attracting more FDI would be a magic wand that triggers economic growth that accomplishes long term program goals. From the early 70s, FDI inflow to Nigeria was marginally stable until the policy of indigenisation/nationalization ${ }^{2}$ which forced

\footnotetext{
${ }^{1}$ Nigeria's Vision 2020:20 is long term plan articulated to lunch Nigeria onto the path of sustainable social and economic growth, and targeted at making Nigeria one of the top 20 economy in the world by 2020 . The benchmark is to raise per capita GDP to US $\$ 4000$, thus improving the welfare of the citizenry.

${ }^{2}$ The Nationalisation/Indigenisation policy was geared at protecting the economy from the control of foreign
} 
foreign investors to withdrew their investments in 1980. The consequence was a drawback in economic growth, though exchange rates remained low and more stable. This unpopular decision was made by a military regime. However, from 1999, when the naira was devalued from 21.88 per dollar to 92.3 per dollar $^{3}$, inward FDI flow fell from US\$1210.11 million to US\$1177.71 million, but changed enormously 3 years later with increases to US\$2040.18 million in 2002 and US\$2171.39 million in 2003 (see Fig 1). Again, despite the world economic crises which made international investors very cynical about emerging markets and developing economies, Nigeria's inward FDI flow significantly increased by $46.07 \%$ in 2011 but declined a bit in 2012. It could also be noted that the UNCTAD, World Investment Reports, announced a rise in global FDI by $9 \%$ with Africa sharing a rise of 4\% in 2013 but FDI flow fell globally by 16\% in 2014 with Africa dropping by 15\%. At this point, Nigeria was earmarked as the biggest destination of FDI in Africa with US\$86,671 million of stock in 2014 despite the Ebola threat that ravaged the West African sub-region.

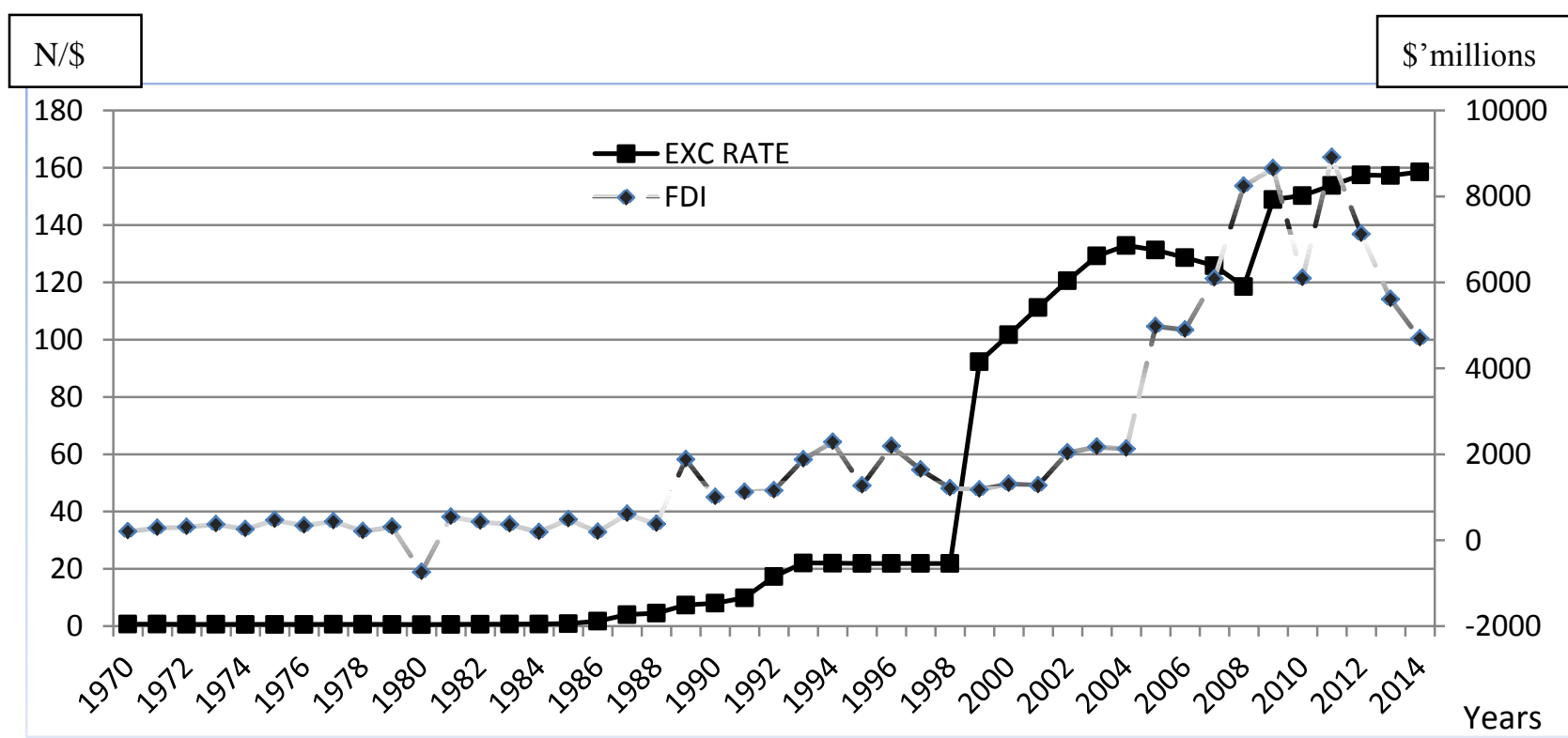

Source of Data: UNCTAD

Figure 1. Flow of FDI and Exchange rate in Nigeria 1970-2014

A good number of authors have argued the importance of exchange rate and its volatility towards FDI inflow; among them are Froot and Stein (1991), Klein and Rosengren (1994), Goldberg and Kolstad (1995), Kiyota and Urata (2004), Xing (2006), Xing and Wan (2006), Ellahi (2011), Ullah et al (2012); some paid more attention to the development in Nigeria (Osinubi and Amaghionyeodiwe 2009, Omokorokunwa and Ikponmwosa 2014). Nevertheless, as it becomes unanimous that exchange rates play a significant role in redirecting FDI flows, there are diverse opinions as to the impacts of volatility on FDI. Writers such as Barrell et al (2003) and Ellahi (2011) would argue there are negative impacts, while others like Cushman (1985) and Goldberg and Kolstad (1995) believe there are positive relations. These distinct opinions are down to what constitutes volatility in the first place; flexibility and uncertainty. The flexibility aspect tends to aid international financial flow, as a result attracts more FDI but the uncertainty leaves the investor to the exposure of high risk which could dissuade the morale of potential foreign investors. Hence, depending on which is dominant, authors are bound to have varying results.

While these authors have made their marks in contributing to development of literature in this regard, their methodology may not be robust and most at times omitted to capture market size effect in GDP. This paper extended the framework of analysis adopted by Kiyota and Urata (2004), Klein and Rosengren (1994) and Froot and Stein (1991), but employed GARCH $(1,1)$ model to examine the extent and nature of volatility of Nigeria's currency (Naira). This paper also captured the political regimes, with dummy variables, from 1970 to 2014. The

hands as FDI was considered as means for economic and political dominance, by converting major companies into government control where government will take up to $40-50 \%$ of the shares.

${ }^{3}$ Again, another decision was made by a military regime before handing over to a democratically elected civilian regime. 
remaining parts of the research work will be segmented into 4 sections; literature review follows immediately, section 3 will design the methodological framework while the domino effect will be analysed in section 4 . Section 5 concludes with findings.

\section{Literature Review}

Generally, the effects of FDI on the host country's economy are reportedly innumerable which includes but not limited to influences on economic growth, employment, production, development, prices, and improve in welfare of the host nation, (Kok and Ersoy 2009). Aside trade, one would agree that FDI is arguably a significant factor engineering globalization of the international economy, but its determinant has been a focal of discourse among scholars. In justifying why firms invest abroad as encapsulated in Dunning's eclectic Paradigm, FDI is motivated by gaining market power (Ownership-specific advantage), benefiting from location specific advantage and conducting operations directly (internalization) rather than through licensing (Dunning 1993). However, there is no consensus as to the determinants of FDI flows. While some authors will have their attention focused on socio-political and institutional reasons such as Hooper and Kim (2007) who verified how opacity index of host countries affect FDI inflow; Schneider and Frey (1985) found that political strikes, riots and regular constitutional changes greatly impede FDI. Rogoff and Reinhart (2003) discovered that institutional and political instability, towering levels of corruption, inactive markets and price volatility inhibits inflow of FDI. (See also Trevino and Mixon 2004). But, there are no appropriate or reliable proxy for political stability/instability.

Moreover, other schools of thought pointed at economic factors which comprises inflation, exchange rate and its volatility, interest rate, market size measured in GDP, and openness as core determinants. This research is partly anchored on this latter school of research, with much emphasis on exchange rate. In analysing determinants of FDI in Germany, Moore (1993) concluded that GDP and market size were key influences while economic growth and trade openness were discovered to have much impact on inward FDI (Morrisset 2000). Similar to the outcome in Asiedu (2002) while analysing 34 sub-Sahara African countries between 1980-2000. Cheng and Kwan (2000) and Zhang (2001) all focused on China and their results revealed that large economic size and better infrastructure, and economic growth, openness, cheap labour, and market size respectively tend to stimulate FDI. Onyeiwu and Shrestha (2004) pinpointed that natural resources, economic growth, openness, inflation and reserve form important motivators to inflow of foreign investment. The research was based on panel data analysis considering 29 African countries for the period of 1975-1995. Market ability could be measured by GDP or GDP per capita, therefore should be envisaged to have positive impact on FDI inflow.

\subsection{FDI and Exchange Rate}

There is good number of empirical research which confirmed the existence of a strong impact of exchange rate on FDI. However, as Kiyota and Urata (2004) explained that an increase in a country's exchange rate (depreciation) is reported to have two effects on FDI attraction. In the first place, it will tend to reduce the production cost of the host Nation against other countries, including the home Nation, with production becoming more efficient in the host country. Second, depreciation of currency in the host Nation would reduce the asset value in the host country, hence attracting more FDI. There seems to be consensus as to how real exchange rates impact FDI. (See Goldberg and Kolstad 1995, Xing and Wan 2006, Udo and Egwaikhide 2008, Osinubi and Amaghionyeodiwe 2009, Dhakal et al 2010, Ellahi 2011, Omokorokunwa and Ikponmwosa 2014). In it all, the failure of the law of one price is believed to prompt the behaviour of real exchange rate and its associated problems. (Rogers and Jenkins 1995, Engel 1999). To attract more foreign investments, most nation tend to devalue their national currency.

\subsection{Exchange Rate Volatility and FDI}

Exchange rate volatility has been examined in different methods and there are varying responses as to its impact on FDI. Exchange rate volatility becomes more controversial due to the lack of definitive conclusion to its effect. In an attempt to investigate how volatility of exchange rates affect flow of US' foreign direct investment to EU, Barrell et al. (2003) used data from 1982-1998 to form a panel of seven industries and employed generalized method of moments (GMM) of which they ascertained a strong negative relationship. Likewise, Brzozowski (2003) also detected negative effects on FDI by using GMM Arellano-Bond model and Fixed Effects OLS to ascertain the impact of exchange rate uncertainty on movement of FDI; considering 32 countries and measuring volatility following GARCH $(1,1)$ method. Tokunbo and Lloyd (2009) utilized a standard deviation technique to measure volatility, while also applying error correction techniques and cointegration to empirically examine the impact of volatility of exchange rate on FDI inflow to Nigeria. Though, the result confirmed a positive relationship between depreciation of naira and inward FDI, exchange rate volatility had no deterministic effect but Udo and Egwaikhide (2008) applied GARCH model and found negative effect with FDI in Nigeria. 
Contrasting opinions abound as Cushman (1985) applied standard deviation of four quarterly values to determine volatility which was applied to ascertain how it impacts on inward FDI. Cushman (1988) adopted mean of four quarterly values to measure volatility and both results indicated that exchange rate volatility positively induce FDI inflow much to the delight of Goldberg and Kolstad (1995) who got similar result as they also applied a standard deviation model to obtain exchange rate volatility-with their study based on FDI flow from Canada, Japan and UK to USA. Stokman and Vlaar (1996) also find a significant positive relationship between exchange rate volatility and Netherland's inward and outward FDI, however, in the long run. Likewise, Chowdhry and Wheeler (2008) and Dhakal et al (2010) attest to the later findings. While Chowdhry and Wheeler (2008) focused on Canada, Japan, UK and USA, the Dhakal et al (2010) study was based on China, Indonesia, Malaysia, Phillippines, South Korea and Thailand.

Osinubi and Amaghionyeodiwe (2009) also utilized a standard deviation model to determine the effect of exchange rate volatility on real inward FDI but got divergent outcomes; the over-parameterized model and the parsimonious model reveals positive and negative impacts respectively. Notwithstanding the method, different results abound from different countries of analysis. The extend of exchange rate volatility could hinge on the exchange rate regime which determines the two aspects of volatility: flexibility and uncertainty. The flexibility side will aid flow of finance across borders while the uncertainty side will deter investors' confidence due to high risk inherent.

\section{Data and Methodology}

\subsection{The Model}

The researcher adopted a model employed by Kiyota and Urata (2004), Klein and Rosengren (1994) and Froot and Stein (1991), not without some augmentations. It could be recalled that to estimate the effects of exchange rate and its volatility on FDI, these authors had expressed similar regressions as follow:

$$
\ln (\mathrm{FDI} / \mathrm{GDPt})=\beta_{1} \ln \left(\mathrm{e}_{\mathrm{t}} \mathrm{P}_{\mathrm{t}} / \mathrm{P}_{\mathrm{t}}\right)+\beta_{2} \mathrm{Vol}_{\mathrm{t}}+\beta_{3} \text { Trend }+\varepsilon_{\mathrm{t}}
$$

Specifically, the regression equation included real exchange rate $\left(e_{t} P_{t} / P_{t}\right)$ and exchange rate volatility $\left(\mathrm{Vol}_{t}\right)$ as explanatory variables, while Kiyota and Urata (2004) also included time Trend to capture frequency of time flows. Yet, an important factor this model gave little or no attention is the market. Despite whatever factors that entice FDI, if the host nation lacks the ability to buy, definitely, lesser FDI will be envisaged. GDP and GDP per capital has generally been use as a proxy to purchasing power of a given Nation, therefore the research reasoned that percentage increase in GDP inflow will cause some percentage increase in foreign investments. Thus, the model could be represented as follow:

$$
\mathrm{F} / \mathrm{Y}_{\mathrm{t}}=\mathrm{F}\left(\mathrm{Y}_{\mathrm{t}}^{\mathrm{R}}, \mathrm{P}_{\mathrm{t}}, \delta_{\mathrm{t}}\right)
$$

Re-written as:

$$
\mathrm{F} / \mathrm{Y}_{\mathrm{t}}=\beta_{10}+\beta_{11} \mathrm{D}_{\mathrm{t}}+\beta_{12} \ln \mathrm{F} / \mathrm{Y}_{\mathrm{t}-1}+\beta_{13} \ln \mathrm{Y}_{\mathrm{t}}^{\mathrm{R}}+\beta_{14} \ln \mathrm{P}_{\mathrm{t}+} \beta_{15} \delta_{\mathrm{t}}+\varepsilon_{\mathrm{t}}
$$

Note: The dependent variable is taken as FDI inflow as percentage of GDP $\left(F / Y_{t}\right)$ to allow for normalization to proxy the real behaviour of FDI inflow. The independent variables include $\mathrm{Y}^{\mathrm{R}}$ representing the real GDP growth rate which was however converted to natural logarithm as $\ln \mathrm{Y}^{\mathrm{R}}{ }_{\mathrm{t}}$, the co-efficient is expected to be $>0 . \mathrm{P}_{\mathrm{t}}$ represents the real exchange rate at time $t$, which is determined using a traditional method as follows: $P_{t}=E_{t} x$ $\mathrm{CPI}_{U S} / \mathrm{CPI}_{\mathrm{NG}}$; Where $\mathrm{P}_{\mathrm{t}}$ stands for annual Real Exchange Rate, $\mathrm{E}_{\mathrm{t}}$ is the nominal exchange rate, $\mathrm{CPI}_{\mathrm{US}}$ is the Price level in USA and $\mathrm{CPI}_{\mathrm{NG}}$ is Price level in Nigeria. The value was also converted to natural logarithm and the co-efficient is expected to be $>0$. $\delta_{\mathrm{t}}$ represent exchange rate volatility which was determined by applying GARCH $(1,1)$. The co-efficient here could either be $>0$ or $<0$ depending on how foreign investors respond to investment risk relation to exchange rate uncertainty. $\mathrm{F} / \mathrm{Y}$ and $\mathrm{Y}^{\mathrm{R}}$ were sourced from UNCTAD while $\mathrm{P}, \delta$ and all the CPI use for data adjustment were obtained from IFS IMF database. $D_{t}$ represents the political regimes which was captured with a dummy variable such that $D_{t}$ equals 1 if in democratic/civilian regime and zero (0) otherwise. The research covered the period between 1970 to 2014, inclusive.

\subsection{The GARCH (1,1) Model}

The researchers choose to apply ARCH/GARCH model popularised by Engel (1982) because as Mckenzie (1999) put it, exchange rate is known to best follow the GARCH process. This represents a technical shift from traditional standard deviation, co-efficient of variance and ratio analysis which are said to lack robustness (Kyereboah-Coleman and Agyire-Tettey 2008). Thus, volatility is calculated as follows:

$$
\ln \mathrm{P}_{\mathrm{t}}=\phi+\lambda \ln \mathrm{P}_{\mathrm{t}-1}+\mathrm{e}_{\mathrm{t}}
$$


where, $\mathrm{e}_{\mathrm{t}} \approx\left(0, \delta_{\mathrm{t}}\right)$ and:

$$
\delta_{\mathrm{t}}=\phi+\omega \mathrm{e}_{\mathrm{t}-1}^{2}+\gamma \delta_{\mathrm{t}-1}+\mu_{\mathrm{t}}
$$

where, the conditional variance $\delta_{\mathrm{t}}$ is dependent of three terms; viz:

(a) The mean $\phi$,

(b) The square error term $\mathrm{e}_{\mathrm{t}-1}^{2}$ in the previous lagged period otherwise known as ARCH term

(c) Previous lag of the conditional variance $\delta_{\mathrm{t}-1}$ also known as GARCH term.

The sum of $\omega+\gamma$ measures the persistency of volatility.

\subsection{Analysis Method}

Auto-regressive Distributed Lag (ARDL) model for co-integration will be adopted for this paper due to its robustness in determining long- and short-run co-efficient. Unlike, the conventional co-integration methods, testing for stationarity will not be compulsory, as it will be convenient to diagnose dynamic interaction between variables when series are not definite whether $I(1)$ or $I(0)$, and one can even determine the parameter of long-and short-run simultaneously. Pesaran et al (2001) reveals that the F-test can be applied to test the joint significant of the lagged-levels of variables in ARDL model with basic condition for co-integration being that computed F-stat falls above the lower- and upper-bounds critical value. Moreover, Banerjee et al (1998) illustrate that a negative and significant error-correction term $\mathrm{ec}_{\mathrm{m}-1}$ could be a different measure to define long-run relationship among variables.

Equation (3) could be altered to the broad form of the Auto-regressive Distributed Lag Model (ARDL) as follows:

$$
\begin{gathered}
\Delta l n \mathrm{~F} / \mathrm{Y}_{\mathrm{t}}=\beta_{10}+\beta_{11} \mathrm{D}_{\mathrm{t}}+\beta_{12} \ln \mathrm{F} / \mathrm{Y}_{\mathrm{t}-1}+\beta_{13} \ln \mathrm{Y}_{\mathrm{t}-1}+\beta_{14} \ln \mathrm{P}_{\mathrm{t}-1}+\beta_{15} \delta_{\mathrm{t}-1}+\sum_{i=0}^{p} \beta_{16} \Delta \ln \mathrm{F} / \mathrm{Y}_{\mathrm{t}-\mathrm{i}}+\sum_{i=0}^{p} \beta_{17} \Delta \ln \mathrm{Y}_{\mathrm{t}-\mathrm{i}}+ \\
\sum_{i=0}^{p} \beta_{18} \Delta \ln \mathrm{P}_{\mathrm{t}-\mathrm{i}}+\sum_{i=0}^{p} \beta_{19} \Delta \delta_{\mathrm{t}-\mathrm{i}}+\varepsilon_{\mathrm{t}}
\end{gathered}
$$

All variables remain as earlier described, $\Delta$ stand for the difference in respective variables and (-) is a lag sign. To satisfy the long-run relationship, ARDL bound test requires a null hypothesis for no co-integration HO: $\beta_{12}=\beta_{13}$ $=\beta_{14}=\beta_{15}=0$; for equation (6).

\section{Analyses of Results}

\subsection{Measuring Volatility Index}

The result of an estimated volatility index is posted in Table 1 which indicates that exchange rate adheres to procedures slated for GARCH $(1,1)$ and is robust. From the conditional variance equation, the mean $(\phi)$ is statistically significant at $1 \%$ level and with a positive co-efficient (22.80938) which suggests a proper classification of conditional variance. Though the ARCH element is negative, the sum of $\omega+\gamma$ is near to 1 which demonstrates persistency of volatility.

The GARCH $(1,1)$ model equations can be substituted for equations 7 and 8 as follows:

$$
\begin{gathered}
\ln \mathrm{P}_{\mathrm{t}}=1.540047+0.949374 \lambda \ln \mathrm{P}_{\mathrm{t}-1} \\
\delta_{\mathrm{t}}=22.80938+-0.118601 \mathrm{e}_{\mathrm{t}-1}^{2}+1.1841 \delta_{\mathrm{t}-1}
\end{gathered}
$$

Table 1. Estimation of volatility Index

\begin{tabular}{llll}
\hline Variable & Coefficient & Std. Error & Z-Statistic \\
\hline$\phi$ & 1.540047 & 3.739623 & 0.411819 \\
$\ln \mathrm{P}_{\mathrm{t}-1}$ & $0.949374^{* * *}$ & 0.018111 & 52.42093 \\
Variance Equation & & & \\
$\phi$ & $22.80938^{* * *}$ & 3.945275 & 5.781442 \\
$\mathrm{ARCH}(-1)$ & $-0.118601^{* * *}$ & 0.001396 & -84.97045 \\
$\mathrm{GARCH}(-1)$ & $1.1841^{* * *}$ & 0.002462 & 480.8829 \\
R-squared & 0.963169 & Akaike info criterion & 9.419362 \\
Adjusted R-squared & 0.962293 & Durbin-Watson stat & 1.893427 \\
\hline
\end{tabular}

Note. The asterisks *** denotes significance at 1\%, Estimation was based on ML-ARCH-Normal distribution following BFGS/Marquardt steps. 


\subsection{Lag Selection Criteria}

With the ARDL model, lag selection is very essential and according to Bahmani-Oskooee and Nasir (2004) and Baek (2014), lag selection is very sensitive such that the result of the F-statistic could be affected. This research therefore employed VAR Lag selection criteria, through which lag 4 was selected give that the asterisk falls mostly on lag 4 with all criteria except for SC. See table 2.

Table 2. VAR Lag Order Selection Criteria

\begin{tabular}{lllllll}
\hline Lag & LogL & LR & FPE & AIC & SC & HQ \\
\hline 0 & -346.4184 & NA & 19.16383 & 17.14236 & 17.35133 & 17.21846 \\
1 & -199.4150 & 250.9815 & 0.050397 & 11.19097 & $12.44481^{*}$ & 11.64755 \\
2 & -179.2403 & 29.52385 & 0.067494 & 11.42636 & 13.72505 & 12.26342 \\
3 & -141.1733 & 46.42323 & 0.041502 & 10.78894 & 14.13250 & 12.00648 \\
4 & -97.85099 & $42.26566^{*}$ & $0.023303^{*}$ & $9.895170^{*}$ & 14.28359 & $11.49319^{*}$ \\
\hline
\end{tabular}

* indicates lag order selected by the criterion

LR: sequential modified LR test statistic (each test at 5\% level)

FPE: Final prediction error

AIC: Akaike information criterion

SC: Schwarz information criterion

HQ: Hannan-Quinn information criterion

\subsection{Results of Bounds Testing for Co-Integration}

It was deemed necessary that dummy variable was introduced such that $D$ takes the value of 0 for periods where Nigeria was a military regime and 1 otherwise. However, the result as posted in Table 3 fulfilled the assumptions of both Banerjee et al (1998) and Pesaran et al (2001), that the $\mathrm{ec}_{m-1}$ is negative $(-0.200989)^{* * *}$ and significant-meaning that the speed of adjustment toward long run equilibrium is $20.09 \%$, and F-statistics (3.947875) fall outside the lower (2.56) and upper bounds (3.49) respectively at 5\% level of significant.

Table 3. Result of Cointegration Bound Test

\begin{tabular}{lllll}
\hline F-statistics & $\mathrm{EC}_{M-1}$ & Significant Level & Lower Bound & Upper Bound \\
\hline 3.947875 & $-0.200989^{* * *}$ & $10 \%$ & 2.2 & 3.09 \\
& $(-5.469985)$ & $5 \%$ & 2.56 & 3.49 \\
& & $1 \%$ & 3.29 & 4.37 \\
\hline
\end{tabular}

Note. number is parenthesis denote the T-statistics and $* * *$ represent $1 \%$ level of significance. F-statistic were determined with unrestricted intercept and no trend

\subsection{Determination of Short-Run and Long-Run Coefficient}

The result of the short-and long-run analyses are posted in table 4 and 5 respectively. A close consideration of both tables will reveal that the effect of exchange rates and exchange rate volatility on inward foreign direct investment in Nigeria are more of a short-run phenomenon than long term. Error correction representation is entreated for short-run co-efficient. First, a percentage increase in FDI will exert a discouraging inflow of more FDIs by at least 0.6 percent, ceteris paribus. This signifies that when more FDI flows into a given sector of the economy, less FDI will be attracted in later periods. Furthermore, income growth of Nigeria as represented by GDP growth rate is a responsible factor that determines more FDI inflow in the country. As the country's GDP growth rate increases by one percent, the result shows that about 0.04 percent of FDI will be multiplied. This result is significant at $1 \%$ level. One would like to point out that GDP growth rate represent the growth in "purchasing power" of the country which means more market for various products.

Similarly, a depreciation of real exchange rates in Nigeria, is one of the determining factor which mostly tend to accelerate inward FDI flow. Currency depreciation will engineer lower assets and production costs, thereby enhancing export of output from said FDI. This goes a long way to encourage more foreign investors. Specifically, all things being equal, an increase in Nigeria's exchange rate by one percent will bring about an increase in FDI of about 1.69 percent.

Regarding volatility, it seems that the flexibility associated with exchange rate fluctuation is being overshadowed by much uncertainty surrounding it, hence, the result posted negative influence of volatility towards inward FDI. 
Investors strive to avoid more risk emanating from exchange rate volatility, which may discourage the enthusiasm of potential foreign investors. Result shows $1 \%$ significant level. The dummy variable posted a positive result, which is also significant at $1 \%$ level. This will also justify that the devaluation of naira in 1999, attracted more FDI.

Table 4. Error Correction Representation for Selected ARDL Model

\begin{tabular}{lllllll}
\hline Variable & $\Delta \ln \mathrm{F} / \mathrm{Y}_{\mathrm{t}-1}$ & $\Delta \ln \mathrm{Y}_{\mathrm{t}}^{\mathrm{R}}$ & $\Delta \ln \mathrm{P}_{\mathrm{t}}$ & $\Delta \delta_{\mathrm{t}}$ & $\mathrm{D}$ & $\mathrm{ec}_{\mathrm{m}-1}$ \\
\hline Lags & 1 & 1 & Level & Level & 3 & 1 \\
Co-efficient & $-0.6624 * * *$ & $0.04224 * * *$ & $1.691 * * *$ & $-0.12 * * *$ & $3.405 * * *$ & $-0.2010^{* * *}$ \\
T-statistics & -5.691 & 2.508 & 3.242 & -2.617 & 4.486 & -5.470 \\
\hline
\end{tabular}

Note. The asterisks ***, ** and $*$ denotes significance at $1 \%, 5 \%$ and $10 \%$ levels respectively, determined with unrestricted intercept and no trend

Though the above co-integration bound test indicated there are long-run relationship, however that relationship is envisaged to have little significance. Primarily, GDP growth rate and real exchange rate seems to have negative influence towards FDI inflow to Nigeria within the period under review, but these results are not significant, hence have little reliance. Unlike popular development in literature review, this suggests that GDP on its own has not much influence on foreign investment inflow in Nigeria in the long run as supported with negative coefficient. On the other hand, the negative sign attached to the co-efficient of real exchange rate illustrates that depreciation will tend to discourage foreign investment in the long-run, all things being equal. These signifies that as both variables converge in the long-run, the sign will tend to change to illustrate such negativity, however, without significance. The sign for volatility remain similar to the short-run analyses but still not significant.

Lastly, democratic dispensation brings about enabling business environment as most foreign investors view a military regime as unpopular and not trusting of foreign investment. The reason being that such regimes are mostly characterised by decrees and tyranny which are mostly not supported by the populace. Therefore, the emergence of democratic dispensation could bring a stable political atmosphere that could breed a better business environment. The result herein has proven thus but still seem to be relevant in the short run only.

Table 5. Estimated long-run co-efficient

\begin{tabular}{llllll}
\hline Variable & $\ln \mathrm{Y}_{\mathrm{t}}^{\mathrm{R}}$ & $\ln \mathrm{P}_{\mathrm{t}}$ & $\delta_{\mathrm{t}}$ & $D$ & $C$ \\
\hline Co-efficient & -0.3763 & -5.4658 & -2.2169 & 2.78799 & 32.1157 \\
T-statistics & -1.1469 & -0.6657 & -1.0362 & 1.00683 & 0.74673 \\
\hline
\end{tabular}

Note. The asterisks ***, ** and $*$ denotes significance at $1 \%, 5 \%$ and $10 \%$ levels respectively, determined with unrestricted intercept and no trend

As matter of necessity, stability test was conducted to determine the suitability and stability of the model applied in this research paper. Cumulative sum of recursive residuals and cumulative sum of squares of recursive residuals indicated perfect stability with no specification errors. This implies that the short run co-efficients in the ECM model are stable and therefore dependable. Jarque-Bera test for Normality, Breusch-Godfrey serial correlation Lagrange Multiplier statistics and Breusch-Pagan-Godfrey Heteroscedasticity test further indicated the model is normal with no sign of serial correlation and heteroscedasticity.

\section{Conclusion}

Exchange rates exert much influence and could be considered key to external transaction be it trade or investment. Therefore, most developing nations consider exchange rates a tool to control balance of payment/current account balances. The motive behind this research was to determine how real exchange rates and its volatility has affected FDI inflow in Nigeria. Recall that Nigeria made some huge decision in their exchange rate regimes which was momentously devaluation at the beginning of 1999 , introducing uncertainty to the Naira mostly at that time. ARDL model was applied to determine the results and it can be concluded that the effects of exchange rate and exchange rate volatility are more of a short-run phenomenon as it has little influence in the long-run. However, devaluation would tend to increase inflow of FDI while volatility could make foreign investors more sceptical implying that they would rather invest with minimal exchange rate risk. Lastly, democratic regime also contributed to increasing FDI flow to Nigeria, just as economic growth did in the short run.

It is therefore very imperative that the country improve on the quality of her democratic regime and the authorities ensure the stability of the naira against dollar. In it all, devaluation of the Naira should be sustained with caution to encourage more inflow of FDI. 


\section{Acknowledgement}

We wish to appreciate the contributions and suggestions of the Reviewers. All errors and omissions remain ours.

\section{References}

Adgbite, E. O., \& Ayadi, F. S. (2010). The Role of Foreign Direct Investment in Economic Development: A Study of Nigeria. The World Journal of Entrepreneurship, Management and Sustainable Development, 6(1-2), 133-147.

Akinlo, A. E. (2004). Foreign Direct Investment and Growth in Nigeria an empirical Investigation, Journal of Policy Modeling, 26, 627-639. https://doi.org/10.1016/j.jpolmod.2004.04.011

Asiedu, E. (2002). On the Determinants of Foreign Direct Investment to Developing Countries: Is Africa Different? World Development, 30(1), 107-119. https://doi.org/10.1016/S0305-750X(01)00100-0

Baek, J. (2014). Exchange Rate Effects on Korea-U.S. Bilateral Trade: A new Look. Research in Economics, 68(3), 214-221. https://doi.org/10.1016/j.rie.2014.05.002

Bahmani-Oskooee, M., \& Nasir, A. B. M. (2004). ARDL Approach to Test the Productivity Bias Hypothesis, Review of Development Economics, 8(3), 483-488. https://doi.org/10.1111/j.1467-9361.2004.00247.x

Banerjee, A., Dolado, J., \& Mestre, R. (1998). Error Correction Mechanism Tests for Cointegration in A Single-Equation Framework. Journal Time Series Analysis, 19(3), 267-283. https://doi.org/10.1111/1467-9892.00091

Barrell, R., Hall, S. G., \& Gottschalk, S. D. (2003). Foreign direct investment and exchange rate volatility in imperfectly competitive markets. National Institute of Economic and Social Research (NIESR), Discussion Papers.

Brozozowski, M. (2003). Exchange Rate Variability and Foreign Direct Investment: Consequences of EMU Enlargement. Centre of Social and Economic Research, Case Study No. 258. https://doi.org/10.2139/ssrn.1441247

Chaudhry, N. I., Mehmood, A., \& Mehmood, M. S. (2013). Empirical Relationship between Foreign Direct Investment \& Economic Growth: ARDL Co-integration Approach for China. China Finance Review International, 3(1), 26-41. https://doi.org/10.1108/20441391311290767

Cheng, L. K., \& Kwan, Y. K. (2000). What are the determinants of the location of foreign direct investment? The Chinese experience. Journal of International Economics, 51(2), 379-400. https://doi.org/10.1016/S0022-1996(99)00032-X

Chowdhury, A., \& Wheeler, M. (2008). Does Real Exchange Rate Volatility Effect Foreign Direct Investment? Evidence from Four Developed Economies. International Trade Journal, 22(2), 218-245. https://doi.org/10.1080/08853900801970601

Cipollina, M., Giovannetti, G., Pietrovito, F., \& Pozzolo, A. F. (2012). FDI and Growth: what cross-country Industry Data say. The World Economy, 35(11), 1599-1629. https://doi.org/10.1111/j.1467-9701.2012.01478.x

Cushman, D. O. (1985). Real Exchange Rate Risk, Expectations, and the Level of Direct Investment. Review of Economics and Statistics, 67(2), 297-308. https://doi.org/10.2307/1924729

Cushman, D. O. (1988). Exchange Rate Uncertainty and Foreign Direct Investment in the United States. Weltwirtschaftliches Archiv (Review of World Economy), 124(2), 322-336. https://doi.org/10.1007/BF02706782

Dhakal, D., Nag, R., Pradhan, G., \& Upadhyaya, K. P. (2010). Exchange Rate Volitility and Foreign Direct Investment: Evidence from East Asian Counteries. International Business \& Economics Research Journal, 09(07), 121-128.

Dunning J. (1993). Multinational Enterprises and the Global Economy. England:Workingham Addison Wesley Publishing.

Ellahi, N. (2011). Exchange rate volatility and foreign direct investment (FDI) behavior in Pakistan: A time series analysis with auto regressive distributed lag (ARDL) application. African Journal of Business Management, 5(29), 11656-11661.

Engel, C. (1999). Accounting for U.S. Real Exchange Rate Changes. Journal of Political Economy, 107(3), 507-538. https://doi.org/10.1086/250070 
Engle, R. F. (1982). Autoregressive Conditional Heteroscedasticity with Estimates of the Variance of United Kingdom Inflation. Econometrica, 50(4), 987-1007. https://doi.org/10.2307/1912773

Froot, K., \& Stein, J. (1991). Exchange Rates and Foreign Direct Investment: An Imperfect Capital Markets Approach. Quarterly Journal of Economics, 106(4), 1191-1217. https://doi.org/10.2307/2937961

Goldberg, L. S., \& Klein, M. (1998). Foreign Direct Investment, Trade, and Real Exchange Rate Linkages in Developing Countries, in R. Glick (ed.), Managing Capital Flows and Exchange Rates: Perspectives from the Pacific Basin (Cambridge, UK: Cambridge University Press), 73-100.

Goldberg, L. S., \& Kolstad, C. D. (1994). Foreign direct investment, exchange rate variability and demand uncertainty. National Bureau of Economic Research, NBER Working Paper Series, Working Paper No. 4815. https://doi.org/10.3386/w4815

Herzer, D. (2012). How Does Foreign Direct Investment Really Affect Developing Countries Growth. Review of International Economics, 20(2), 396-414. https://doi.org/10.1111/j.1467-9396.2012.01029.x

Hooper, V. and Kim, S. (2007). The determinants of capital inflows: does Capacity of recipient country explain the flows?", Economic Systems, 31(1), 35-48. https://doi.org/10.1016/j.ecosys.2006.08.001

Kiyota, K., \& Urata, S (2004). Exchange Rate, Exchange Rate Volatility and Foreign Direct Investment. The World Economy, 27(10), 1501-1536. https://doi.org/10.1111/j.1467-9701.2004.00664.x

Klein, M. W., \& Rosengren, E. (1994). The Real Exchange Rate and Foreign Direct Investment in the United States: Relative Wealth vs. Relative Wage Effects. Journal of International Economics, 36(3-4), 373-389. https://doi.org/10.1016/0022-1996(94)90009-4

Kok, R., \& Ersoy, B. A. (2009). Analyses of FDI Determinants in Developing Countries. International Journal of Social Economics, 36(1-2), 105-123. https://doi.org/10.1108/03068290910921226

Kyereboah-Coleman, A., \& Agyire-Tettey, K. F. (2008). Effect of Exchange-Rate Volatility on Foreign Direct Investment in Sub-Saharan Africa. The Journal of Risk Finance, 9(1), 52-70. https://doi.org/10.1108/15265940810842410

Liu, X., Luo, Y., Qiu, Z., \& Zhang, R. (2014). FDI and Economic Development: Evidence from China's Regional Growth. Emerging Market Finance and Trade, 50(6), 87-106. https://doi.org/10.1080/1540496X.2014.1013852

McCloud, N., \& Kumbhakar, S. C. (2011). Institution Foreign Direct Investment and growth: A hierarchical Bayesian Approach. Journal of the Royal Statistical Society; Series A (Statistics in Society), 175(1), 83-105. https://doi.org/10.1111/j.1467-985X.2011.00710.x

McKenzie, M. D. (1999). The Impact of Exchange Rate Volatility on International Trade Flows. Journal of Economic Surveys, 13(1), 71-106. https://doi.org/10.1111/1467-6419.00075

Moore, M. O. (1993). The determinants of German manufacturing direct investment: 1980-1988. Weltwirschaftliches Archive, 129(1), 739-773. https://doi.org/10.1007/BF02707490

Morisset, P. (2000). Foreign direct investment to Africa: policies also matter. Transnational Corporation, 9(2) 107-125.

Muhammad, B., Muhammad, I., Amjad, A., Muhammad, S., Mansoor, A., Iltaf, H., \& Tehreem, F. (2014). Impact of Exchange Rate on Foreign Direct Investment in Pakistan. Advances in Economics and Business 2(6), 223-231.

Omorokunwa, O. G., \& Ikponmwosa, N. (2014). Exchange Rate Volatility and Foreign Private Investment in Nigeria. Asian Journal of Business Management, 6(4), 146-154. https://doi.org/10.19026/ajbm.6.5157

Onyeiwu, S., \& Shrestha, H. (2004). Determinants of foreign direct investment in Africa. Journal of Developing Societies, 20(1-2), 89-106. https://doi.org/10.1177/0169796X04048305

Osinubi, T. S., \& Amaghionyeodiwe, L. A. (2009). Foreign direct investment and exchange rate volatility in Nigeria. International Journal of Applied Econometrics and Quantitative Studies, 6(2), 1-13.

Pesaran, M. H., Shin, Y., \& Smith, R. J. (2001). Bounds Testing Approaches to the Analysis of Level Relationships. Journal of Applied Econometrics, 16(3), 289-326. https://doi.org/10.1002/jae.616

Rehman, N. U. (2016). FDI and Economic Growth: Empirical Evidence from Pakistan. Journal of Economic and Administrative Sciences, 32(1), 63-76. https://doi.org/10.1108/JEAS-12-2014-0035 
Rogers, J. H., \& Jenkins, M. (1995). Haircuts or Hysteresis? Sources of Movements in Real Exchange Rates. Journal of International Economics, 38(3-4), 339-360. https://doi.org/10.1016/0022-1996(94)01354-U

Rogoff, K. and Reinhart, C. (2002). FDI to Africa: the role of price stability and currency instability. paper presented at The Annual World Bank Conference on Development Economics, Washington DC, April 29-30

Schneider, F., \& Frey, B. (1985). Economic and political determinants of foreign direct investment. World Development, 13(2), 161-175. https://doi.org/10.1016/0305-750X(85)90002-6

Stokman, A. C. J., \& Vlaar, P. J. G. (1996). Volatility, International Trade and Capital Flows, in Bruni F., Fair D.E. and R. O’Brien (Eds), Risk Management in Volatile Financial Markets. 32, 115-132, Kluwer Academic Publishers, Amsterdam.

Tokunbo, S. O., \& Lloyd, A. A. (2009). Foreign direct investment and exchange rate volatility in Nigeria. International Journal of Applied Econometrics and Quantitative Studies, 9(2), 83-116.

Trevin, L. J., \& Mixon, F. G. Jr. (2004). Strategic factors affecting foreign direct investment decisions by multi-national enterprises in Latin America. Journal of World Business, 39(3), 233-243. https://doi.org/10.1016/j.jwb.2004.04.003

Udoh, E., \& Egwaikhide, F. O. (2008). Exchange Rate Volatility, Inflation Uncertainty and Foreign Direct Investment in Nigeria. BOJE: Botswana Journal of Economics, 5(7), 14-31.

Ullah, S., Haider, S. Z., \& Azim, P. (2012). Impact of Exchange Rate Volatility on Foreign Direct Investment: A Case Study of Pakistan. Pakistan Economic and Social Review, 50(2), 121-138

UNCTAD 2014, World Investment Reports.

Wang, M., \& Wong, M. C. S. (2008). Foreign Direct Investment and Economic growth: The Growth Accounting Perspective. Economic Inquiring, 47(4), 701-710. https://doi.org/10.1111/j.1465-7295.2008.00133.x

Xing, Y. (2006). Why is China so Attractive for FDI? The Role of Exchange Rates. China Economic Review 17(2), 198-209. https://doi.org/10.1016/j.chieco.2005.10.001

Xing, Y., \& Wan, G. (2006). Exchange Rates and Competition for FDI in Asia. The World Economy, 29(4), 419-434. https://doi.org/10.1111/j.1467-9701.2006.00791.x

Zhang, K. H. (2001). What Attracts Foreign Multinational Corporations to China? Contemporary Economic Policy, 19(3), 336-346. https://doi.org/10.1093/cep/19.3.336

Zhao, C., \& Du, J. (2007). Causality between FDI and Economic growth in China. The Chinese Economy, 40(6), 68-82. https://doi.org/10.2753/CES1097-1475400604

\section{Copyrights}

Copyright for this article is retained by the author(s), with first publication rights granted to the journal.

This is an open-access article distributed under the terms and conditions of the Creative Commons Attribution license (http://creativecommons.org/licenses/by/4.0/). 